\title{
Pentingnya Pengambilan Keputusan Dalam Pemecahan Masalah Asuhan Keperawatan
}

\author{
Fitri Rahmadani Siregar \\ danisiregar1001@gmail.com
}

\section{Latar Belakang}

Pengambilan keputusan sangat penting keberadaannya dalam asuhan maupun dalam manajemen keperawatan. Pengambilan keputusan merupakan suatu proses yang mencakup semua penilaian kegiatan yang diperlukan guna membuktikan dan meperlihatkan pilihan terbaik dalam menyelesaiakan suatu masalah tertentu. Setiap keputusan adalah akibat dari sebuah proses dinamis yang dipengaruhi oleh banyak kekuatan. Pengambilan keputusan bukan merupakan prosedur yang tetap akan tetapi sebuah proses yang beruntun.

Kemampuan membuat keputusan masalah etis menjadi salah satu persyaratan bagi perawat untuk menjalankan praktik keperawatan professional. Pengambilan keputusan merupakan suatu pendekatan sistematis untuk menyelesaikan suatu masalah. Proses pengambilan keputusan merupakan komponen penting dalam proses keperawatan, sehingga dibutuhkan pengetahuan dan kemampuan perawat. Jika perawat memiliki keterbatasan pengetahuan dan kemampuan, maka hal tersebut dapat menghambat perawat dalam mengambil keputusan mengenai perawatan yang akan diberikan kepada klien yang akan berakibat fatal terhadap klien.

Pengambilan keputusan adalah suatu pendekatan yang sistematis terhadap hakekat suatu masalah dengan pengumpulan fakta-fakta dan data, menentukan alternatif yang matang untuk mengambil suatu tindakan yang tepat. Pengambilan keputusan dalam penyelesaian masalah adalah kemampuan mendasar bagi praktisi kesehatan, khususnya dalam asuhan keperawatan dan kebidanan. Tidak hanya berpengaruh pada proses pengelolaan asuhan keperawatan dan kebidanan, tetapi penting untuk meningkatkan kemampuan merencanakan perubahan. Perawat dan bidan pada semua tingkatan posisi klinis harus memiliki kemampuan menyelesaikan masalah dan mengambil keputusan yang efektif, baik sebagai pelaksana/staf maupun sebagai pemimpin. Penyelesaian masalah dan pengambilan keputusan bukan merupakan bentuk sinonim. Pemecahan masalah dan proses pengambilan keputusan 
membutuhkan pemikiran kritis dan analisis yang dapat ditingkatkan dalam praktek. Pengambilan keputusan merupakan upaya pencapaian tujuan dengan menggunakan proses yang sistematis dalam memilih alternatif. Tidak semua pengambilan keputusan dimulai dengan situasi masalah. Pemecahan masalah termasuk dalam langkah proses pengambilan keputusan, yang difokuskan untuk mencoba memecahkan masalah secepatnya. Masalah dapat digambarkan sebagai kesenjangan diantara "apa yang ada dan apa yang seharusnya ada". Pemecahan masalah dan pengambilan keputusan yang efektif diprediksi bahwa individu harus memiliki kemampuan berfikir kritis dan mengembangkan dirinya dengan adanya bimbingan dan role model di lingkungan kerjanya.

\section{Metode}

Pada pengkajian ini digunakan metode kualitatif, yang dimana metode ini lebih cenderung bersifat memberikan penjelasan dengan menggunakan analisis berdasarkan landasan teori dan juga dengan metode membaca dan literasi data dari berbagai sumber seperti buku, jurnal, ebook, artikel ilmiah, dan karya tulis ilmiah yang berfokus pada pentingnya pengambilan keputusan dalam pemecahan masalah asuhan keperawatan di Rumah Sakit. Metode dari penulisan ini juga dilakukan untuk menjelaskan terkait tahapan pengambilan keputusan seorang perawat dalam mengambil keputusan.

\section{Hasil}

Hasil dari pengkajian menggunakan metode penulisan kualitatif adalah menghasilkan suatu pembelajaran tentang pentingnya pengambilan keputusan dalam pemecahan masalah asuhan keperawatan di Rumah Sakit melalui pengumpulan data berdasarkan buku teks, jurnal atau karya tulis ilmiah.

Keputusan dalam penyelesaian masalah adalah kemampuan mendasar bagi praktisi kesehatan, khususnya dalam asuhan keperawatan. Tidak hanya berpengaruh pada proses pengelolaan asuhan keperawatan, tetapi penting untuk meningkatkan kemampuan merencanakan perubahan. Perawat pada semua tingkatan posisi klinis harus memiliki kemampuan menyelesaikan masalah dan mengambil keputusan yang efektif, baik sebagai pelaksana/staf maupun sebagai pemimpin. 
Pemecahan masalah dan proses pengambilan keputusan membutuhkan pemikiran kritis dan analisis yang dapat ditingkatkan dalam praktek. Pengambilan keputusan merupakan upaya pencapaian tujuan dengan menggunakan proses yang sistematis dalam memilih alternatif. Tidak semua pengambilan keputusan dimulai dengan situasi masalah.

Pemecahan masalah termasuk dalam langkah proses pengambilan keputusan, yang difokuskan untuk mencoba memecahkan masalah secepatnya. Masalah dapat digambarkan sebagai kesenjangan diantara "apa yang ada dan apa yang seharusnya ada". Pemecahan masalah dan pengambilan keputusan yang efektif diprediksi bahwa individu harus memiliki kemampuan berpikir kritis dan mengembangkan dirinya dengan adanya bimbingan dan role model di lingkungan kerjanya. Seorang perawat dalam pemecahan masalah harus senantiasa mendapatkan informasi untuk mengklarifikasi sifat masalah dan mencari solusi dalam pemecahan masalah yang dihadapi oleh klien. Kemudian secara seksama mengevaluasi solusi dan memilih solusi terbaik untuk diimplementasikan. Beberapa langkah-langkah dapat digunakan dalam pemecahan masalah, seperti hal berikut:

1. Mengetahui hakekat dari masalah dengan mendefinisikan masalah yang dihadapi.

2. Mengumpulkan fakta-fakta dan data yang relevan.

3. Mengolah fakta dan data.

4. Menentukan beberapa alternatif pemecahan masalah.

5. Memilih cara pemecahan dari alternatif yang dipilih.

6. Memutuskan tindakan yang akan diambil.

7. Evaluasi.

\section{Pembahasan}

Institusi Kesehatan dunia tahun 2017 mengindentifikasi 98.000 pasien meninggal setiap tahun akibat pengambilan keputusan yang buruk dalam perawatan kesehatan. Pengambilan keputusan sangat penting dalam menentukan asuhan keperawatan kepada pasien. Perawat harus mempertimbangkan banyak faktor yang berpotensi mempengaruhi proses pengambilan keputusan dalam memenuhi kebutuhan pasien (Cristine W. Nibbelink, 2017). Perawat harus mempunyai kemampuan yang baik untuk pasien maupun dirinya didalam menghadapi masalah yang menyangkut etika. Seseorang harus berpikir secara rasional, bukan emosional dalam membuat keputusan etis. Keputusan tersebut membutuhkan keterampilan berpikir 
secara sadar yang diperlukan untuk menyelamatkan keputusan pasien dan memberikan asuhan. Kemampuan membuat keputusan masalah etis menjadi salah satu persyaratan bagi perawat untuk menjalankan praktik keperawatan professional (Haryono, 2012).

Pengambilan keputusan yang tepat menggunakan suatu pendekatan yang sistematis terhadap hakekat suatu masalah dengan pengumpulan fakta-fakta dan data. Dalam menentukan alternatif yang matang untuk mengambil suatu tindakan yang tepat didasarkan pada kriteria tertentu atas dua atau lebih alternatif yang sesuai (George R. Terry, 2019). Pengambilan keputusan dalam penyelesaian masalah membutuhkan kemampuan yang mendasar bagi praktisi kesehatan, khususnya dalam asuhan keperawatan (Dolan, 2017). Pengambilan keputusan tidak hanya berpengaruh pada proses pengelolaan asuhan keperawatan, tetapi penting untuk meningkatkan kemampuan merencanakan perubahan. Perawat pada semua tingkatan posisi klinis harus memiliki kemampuan menyelesaikan masalah dan mengambil keputusan yang efektif, baik sebagai pelaksana/staf maupun sebagai pemimpin (Dolan, 2017; Nursalam, 2014).

Ada lima hal yang perlu diperhatikan dalam pengambilan keputusan:

1. Dalam proses pengambilan keputusan tidak terjadi secara kebetulan.

2. Pengambilan keputusan tidak dilakukan secara sembrono tapi harus berdasarkan pada sistematika tertentu:

a. Tersedianya sumber-sumber untuk melaksanakan keputusan yang akan diambil.

b. Kualifikasi tenaga kerja yang tersedia

c. Falsafah yang dianut organisasi.

d. Situasi lingkungan internal dan eksternal yang akan mempengaruhi administrasi dan manajemen di dalam organisasi.

3. Masalah harus diketahui dengan jelas.

4. Pemecahan masalah harus didasarkan pada fakta-fakta yang terkumpul dengan sistematis.

5. Keputusan yang baik adalah keputusan yang telah dipilih dari berbagai alternatif yang telah dianalisa secara matang.

Proses dasar pembuatan keputusan mencakup identifikasi dan diagnosa masalah yaitu mengenali (mengidentifikasi) dan menentukan (mendefinisikan) masalah, pengumpulan data yang relevan yaitu menentukan data-data apa yang akan dibutuhkan untuk membuat keputusan yang tepat dan kemudian mendapatkan informasi tersebut, pengembangan alternatif yaitu pencarian solusi potensial untuk masalah tersebut guna memperoleh informasi 
sehingga dapat dikembangkan menjadi alternatif yang mungkin, evaluasi alternatif yaitu mengevaluasi untuk menilai efektivitas setiap alternatif dengan melihat dampak positif dan dampak negatifnya, pemilihan alternatif terbaik yaitu memecahkan masalah guna mencapai tujuan yang direncanakan sebelumnya, implementasi keputusan yaitu menguji keputusan dengan melihat perilaku orang yang dipengaruhi keputusan itu serta pengendalian dan evaluasi yaitu Perubahan, jika perlu dibuat solusi yang dipilih pada saat implementasi, atau jika tujuan awal dianggap tidak tercapai.

Berpikir kritis juga sangat penting dilakukan oleh perawat sebelum mengambil keputusan dalam asuhan keperawatan.Asuhan keperawatan merupakan satu metode ilmiah dalam penyelesaian masalah klien. Kemampuan perawat mengidentifikasi masalah klien dan memilih solusi intervensi yang tepat tidak lepas dari kemampuan perawat berpikir kritis, yaitu kemampuan perawat menggali alas an dari setiap masalah dan solusi yang teridentifikasi.

Pengambilan keputusan merupakan proses pemecahan masalah yang berfokus pada analisa situasi yang sulit untuk mengambil solusi yang memutuskan permasalah tersebut. Oleh karena itu seorang perawat dituntut untuk dapat memutuskan sesuatu dengan baik dan tidak merugikan orang lain yang berlandaskan etika profesi keperawatan. Dalam pengambilan keputusan perawat harus mempertimbangkan segala aspek, baik dari pasien itu sendiri, keluarga pasien, tenaga kesehatan lain, dan psiko, sosial, dan cultural yang diterapkan.

Perawat dapat menggunakan panduan berikut ini untuk pemprosesan dan pengambilan keputusan, yaitu:

a. Menunjukkan maksud baik

Penting bagi perawat dan semua tim yang terlibat mengikuti diskusi dengan anggapan bahwa semua tim menemukan apa yang baik bagi tidakan yang akan diberikan kepada klien. Diskusi harus dimulai dengan etika baik dan kepercayaan pada semua anggota tim, jika tidak dimulai dengan saling percaya dan prinsip berbuat baik maka hasil yang diputuskan tidak akan memberikan kebaikan pada klien dan mencegah terjadinya kesalahan dan kejahatan pada klien dan keluarganya.

b. Mengidentifikasi semua orang penting

Sebelum pengambilan keputusan, perawat hendaknya mengingatkan bahwa semua orang/anggota tim ikut serta dalam proses pengambilan keputusan adalah penting. Tidak menilai seberapa besar porsi nilai yang diberikan oleh masing-masing anggota 
tim, prinsipnya bahwa keputusan yang diambil adalah keputusan bersama atau keputusan tim.

c. Mengumpulkan informasi yang relevan

Menggali atau mengumpulkan semua informasi sangatlah penting sebelum keputusan diambil. Informasi yang relevan meliputi data tentang pilihan klien, sistem keluarga, diagnosa dan prognosa medis, pertimbangan sosial dan dukungan lingkungan. Perawat atau tim perawat tidak dapat mengambil keputusan yang baik jika berdasarkan data-data atau informasi yang lemah. Oleh karena itu, perawat harus mampu mengumpulkan informasi yang paling relevan sebagai dasar pengambilan keputusan etis bagi klein.

d. Mengidentifikasi prinsip etis yang penting

Keputusan etis harus didasari dengan prinsip etis yang sesuai, walaupun prinsip etis yang umum dan universal tidak dapat menunjukkan pada perawat apa yang harus ia lakukan dalam situasi kritis. Tetapi prinsip etis tersebut tetap harus dijadikan standar pegangan bagi perawat untuk mengambil keputusan etis, karena dapat membantu menilai dalam situasi dilema tersebut. Sehingga dapat mencari solusi untuk mengesampingkan atau menghilangkan hal yang dapat menghalangi norma dan nilai keputusan etis akan menjadi lebih baik.

e. Mengusulkan tindakan alternatif

Perawat seringkali sulit mengatasi masalah yang dihadapi karena mereka hanya dapat melihat satu tindakan yang mungkin dapat diberikan kepada klien. Tanpa memberikan kebebasan untuk menentukan pilihan yang masuk akal yang dapat melindungi nilai kemanusiaan yang pada orang-orang yang terlibat.

f. Melakukan tindakan

Begitu keputusan etis telah diambil berdasarkan hasil diskusi tim yang dilakukan secara terbuka dengan melibatkan semua unsur yang terkait, maka perawat atau tim dapat mengimplementasikannya dalam bentuk tindakan keperawatan sesuai dengan standar asuhan keperawatan.

\section{Penutup}

Pengambilan keputusan (decision making) merupakan hal yang sangat penting untuk diperhatikan oleh perawat berkaitan dengan kualitas pemberian asuhan keperawatan. Keputusan dalam penyelesaian masalah adalah kemampuan mendasar bagi praktisi 
kesehatan, khususnya dalam asuhan keperawatan. Tidak hanya berpengaruh pada proses pengelolaan asuhan keperawatan, tetapi penting untuk meningkatkan kemampuan merencanakan perubahan. Perawat pada semua tingkatan posisi klinis harus memiliki kemampuan menyelesaikan masalah dan mengambil keputusan yang efektif, baik sebagai pelaksana/staf maupun sebagai pemimpin.

\section{Referensi}

Ardiyani, V. M. (2018). Analisis peran perawat terhadap ketepatan penentuan prioritas i, ii, \& iii pada ruang triage di IGD RS dr. Saiful Anwar Malang. Jurnal Ners LENTERA, 6(2), 103113.

Anwar, H. (2014). Proses Pengambilan Keputusan untuk Mengembangkan Mutu Madrasah. Jurnal Pendidikan Islam, Vol 8 No 1, 38-56.

Budiono \& Pertami, S. B. (2016). Konsep Dasar Keperawatan. Jakarta: Bumi Medika

Deniati, K., Anugrahwati, R. \& Suminarti, T. (2018). Pengaruh berfikir kritis terhadap kemampuan perawat pelaksana dalam melakukan asuhan keperawatan di RS Hermina Bekasi tahun 2016. Jurnal Kesehatan Holistik, 12(1), 21-25.

Khairina, I., dkk. (2018). Faktor-Faktor Yang Berhubungan Dengan Pengambilan Keputusan Perawat Dalam Ketepatan Triase Di Kota Padang. Indonesian Journal for Health Sciences, Vol.2, No.1, 1-6.

Moordiningsih, \& Faturochman. (2015). Proses Pengambilan Keputusan Dokter (Physician Decision Making). Jurnal Psikologi. 33 (2), hal 1 - 15.

Pashar, I. \& Dwiantoro, L. (2020). Pengaruh empowerment terhadap pengambilan keputusan perawat: Kajian literature review. Journal of Holistic Nursing Science, 7(2), 124-132.

Purwati, E. I. I., Nuryadi, \& Herawati, Y. T. (2017). Pengambilan keputusan dalam pelaksanaan rujukan puskesmas sebagai fasilitas kesehatan tingkat pertama. e-Jurnal Pustaka Kesehatan, 5(2), 231-238. 
Rahayu, C. D. \& Mulyani, S. (2020). Pengambilan keputusan klinis perawat. Jurnal Ilmu Kesehatan, 10(1), 1-11.

Simamora, R. H. (2019). Menjadi perawat yang: CIH'HUY. Surakarta: Kekata Publisher.

Simamora, R. H. (2005). Hubungan Persepsi Perawat Pelaksana Terhadap Penerapan

Fungsi Pengorganisasian Yang Dilakukan Oleh Kepala Ruangan Dengan Kinerjanya Diruang Rawat Inap RSUD Koja Jakarta Utara (Doctoral dissertation, Tesis FIK UI, Tidak dipublikasikan).

Sudono, B., Setya, D., \& Atiningtyas, R. (2017). Gambaran kemampuan berpikir kritis perawat primer dalam pelaksanaan asuhan keperawatan di RS Islam Surakarta. Jurnal Ilmu Keperawatan Indonesia, 10(1), 79-106. 